\section{PENANGANAN PELANGGARAN HUKUM DI ZONA EKONOMI EKSKLUSIF PERAIRAN NATUNA ${ }^{1}$ \\ Oleh: Ryfan Jushua Medendehe ${ }^{2}$ \\ Flora P. Kalalo 3 \\ Fernando J. M. M. Karisoh ${ }^{4}$}

\begin{abstract}
ABSTRAK
Tujuan dilakukannya penelitian ini adalah untuk mengetahui bagaimana terjadinya pelanggaran hukum di Zona Ekonomi Eksklusif Perairan Natuna dan bagaimana penanganan pelanggaran hukum di Zona Ekonomi Eksklusif Perairan Natuna. Dengan menggunakan metode penelitian yuridis normative, disimpulkan: 1 . Terjadinya pelanggaran hukum di zona ekonomi eksklusif perairan natuna, seperti kegiatan illegal fishing yang dilakukan oleh nelayan-nelayan asing dari Cina, Vietnam. Kasus lainnya yang tercatat ialah penggunaan bahan peledak pencurian, penyelundupan pekerja imigran Indonesia, migas, illegal logging, illegal minning, penyelundupan kepabeanan dan perompakan. Perairan yang rawan pencurian, antara lain, laut Natuna yang berbatasan dengan laut Cina Selatan, perairan Sulawesi Utara yang berbatasan dengan Samudra Pasifik dan Laut Arafura. Pencurian ikan oleh kapal-kapal asing dilakukan secara terang-terangan, menggunakan alat tangkap pukat harimau (trawl). Penyebab terjadinya kegiatan illegal fishing di perairan Indonesia, antara lain, karena terbatasnya sarana dan prasarana pengawasan untuk melakukan penegakan hukum. 2. Penanganan pelanggaran hukum di zona ekonomi eksklusif perairan natuna, dilakukan melalui upaya penegakan hukum oleh instansi pemerintah terkait yang mengatur bidang kelautan.
\end{abstract}

Kata kunci: Penanganan, Pelanggaran Hukum, Zona Ekonomi Eksklusif, Perairan Natuna

\section{PENDAHULUAN}

\section{A. Latar Belakang}

Indonesia merupakan negara kepulauan terbesar di dunia dengan luas lautanya sebesar $75 \%$ dari luas daratannya atau sekitar 6 juta

\footnotetext{
${ }^{1}$ Artikel Skripsi

2 Mahasiswa pada Fakultas Hukum Unsrat, NIM : 16071101195

${ }^{3}$ Fakultas Hukum Unsrat, Doktor IImu Hukum

${ }^{4}$ Fakultas Hukum Unsrat, Magister IImu Hukum
}

$\mathrm{Km}^{2}$, Indonesia juga mempunyai garis pantai sepanjang lebih kurang $81.000 \mathrm{Km}$ dan merupakan garis pantai terpanjang kedua di dunia. Berdasarkan Konvensi Hukum Laut 1982 (UNCLOS 1982), Indonesia mempunyai kedaulatan atas wilayah perairan seluas $3,2 \mathrm{Km}^{2}$ yang terdiri dari Perairan Kepulauan seluas 2,9 juta $\mathrm{Km}^{2}$ dan laut Teritorial seluas 0,3 juta $\mathrm{Km}^{2}$.

Selain itu, wilayah laut kita memiliki potensi sumberdaya alam yang luar biasa yang sampai saat ini belum dikelola secara optimal. Kita juga mempunyai hak berdaulat atas sumberdaya alam laut tersebut dan berbagai kepentingan yang terkait pada perairan ZEE seluas 2.7 juta $\mathrm{Km}^{25}$

Pada tanggal 31 Desember 1985 Indonesia, telah meratifikasi UNCLOS 1982 melalui pengundangan UU No. 17 Tahun 1985 tentang Pengesahan United Nations Convention on the Law of the Sea 1982. Sebagai pelaksanaan lebih lanjut dari ratifikasi ini, pada tahun 1996, pemerintah mencabut UU No. 4/Prp/1960 dan menggantinya dengan UU No. 6 Tahun 1996 tentang Perairan Indonesia yang lebih disesuaikan dengan UU No. 6 Tahun 1996 tentang Perairan Indonesia yang lebih disesuaikan dengan ketentuan-ketentuan UNCLOS $1982 .{ }^{6}$

Indonesia membentang luas di wilayah sekitar katulistiwa (equator) di Asia Pasifik dari $94^{\circ}$ Bujur Timur (BT) sampai dengan $141^{\circ}$ Bujur Timur (BT) dan $6^{\circ}$ Lintang Utara (LU) sampai $11^{\circ}$ Lintang Selatan (LS), merupakan negara kepulauan terbesar di dunia. Indonesia terdiri dari banyak pulau yang sebagian besar berada di bawah permukaan laut. Dibandingkan luasnya dengan kontinen Eropa, Amerika dan Australia, maka wilayah laut Indonesia layak disebut sebagai benua maritime (Maritime Continent). ${ }^{7}$

Terjadinya pelanggaran hukum di zona ekonomi eksklusif perairan natuna dan mekanisme penanganan-penanganan pelanggaran hukum di zona ekonomi eksklusif perairan natuna harus dilaksanakan sesuai

\footnotetext{
${ }^{5}$ Etty R. Agoes (Penyunting) Dimanahkah Batas-Batas Wilayah Kita Di Laut ? Departemen Kelautan dan Perikanan, Jakarta, 13 Desember 2000, hlm. 1.

${ }^{6} \mathrm{lbid}$.

${ }^{7}$ Sukandarrumidi, Mari Kembali Ke Laut (Mengenal Potensi Bahari Yang Tak Habis Terkuras) Dengan Studi Kasus, Cetakan Pertama, Yayasan Pustaka Nusatama, Yogyakarta, 2009 hlm. 12-13.
} 
dengan perjanjian internasional di bidang hukum laut dan peraturan perundangundangan yang berlaku untuk memberikan kepastian hukum dan jaminan perlindungan hukum terhadap pelaksanaan kewenangan Negara Republik Indonesia di perairan zona ekonomi eksklusif Indonesia. Oleh karena itu pengkajian diperlukan untuk melihat proses terjadinya pelanggaran hukum di Zona Ekonomi Eksklusif Perairan Natuna. Dalam lingkup yang mendalam juga penting untuk dikaji penanganan pelanggaran hukum di Zona Ekonomi Ekslusif Perairan Natuna.

Dari penjelasan di atas maka penulis tertarik untuk melakukan penelitian dengan judul: "PENANGANAN PELANGGARAN HUKUM DI ZONA EKONOMI EKSKLUSIF PERAIRAN NATUNA".

\section{B. Perumusan Masalah}

1. Bagaimana terjadinya pelanggaran hukum di Zona Ekonomi Eksklusif Perairan Natuna?

2. Bagaimana penanganan pelanggaran hukum di Zona Ekonomi Eksklusif Perairan Natuna?

\section{Metode Penelitian}

Penelitian hukum normatif digunakan dalam menyusun penulisan ini. Metode penelitian hukum normatif menggunakan bahan-bahan hukum yang dikumpulkan melalui studi kepustakaan dan terdiri dari:

1. Bahan-bahan hukum primer: peraturan perundang-undangan di bidang kelautan.

2. Bahan-bahan hukum sekunder: literaturliteratur, karya-karya ilmiah hukum, jurnal hukum dan referensi ilmu hukum lainnya.

3. Bahan-bahan hukum tersier: kamus umum dan kamus hukum.

\section{PEMBAHASAN}

\section{A. Pelanggaran Hukum di Zona Ekonomi Eksklusif Perairan Natuna}

Salah satu kasus yang terjadi pada 28 April 2019, merekam insiden saat kapal pengawas perikanan milik pemerintah Vietnam menabrak kapal perang Indonesia, KRI Tjiptadi 381. Kejadian bermula saat KRI Tjiptadi-381 melaksanakan Penegakan Hukum di ZEE Indonesia, tepatnya di Laut Natuna Utara, terhadap Kapal Ikan Asing (KIA) Vietnam BD 979 yang sedang melaksanakan Illegal Fishing (pencurian ikan) dan akan menangkap KIA Vietnam tersebut, namun KIA Vietnam tersebut dikawal oleh Kapal Pengawas Perikanan Vietnam, kapal pengawas perikanan Vietnam berusaha menghalangi proses penegakan hukum yang dilakukan oleh KRI Tjiptadi-381. ${ }^{8}$

Dua kapal pengawas perikanan Vietnam KN 264 dan KN 231 telah dengan sengaja menabrakan diri ke KRI Tjiptadi-381 yang sedang membawa Kapal Ikan Asing (KIA) Vietnam BD 979 yang tertangkap melakukan pencurian ikan di perairan Indonesia khususnya wilayah utara perairan Natuna. Dari kejadian ini tidak saja merusak KRI Tjiptadi-381, bahkan KIA Vietnam BD 979 juga mengalami kebocoran hingga akhirnya tenggelam akibat ditabrak kapal pengawasan Vietnam tersebut. ${ }^{9}$

Di insiden tersebut, 2 kapal pengawas perikanan Vietnam mengganggu proses penegakan hukum yang dilakukan KRI Tjiptadi381. KN 264 dan KN 231 semula bermanuver dengan mendekati Kapal Ikan Asing Vietnam (KIAV) BD 979 dan beberapa kali menabraknya hingga bagian bakatnya rusak. KRI Tjiptadi tak menghiraukan manuver KN 264 dan KN 231 dengan tetap menggiring KIAV BD 979 ke Lanal Ranai. Namun, ternyata KN 264 lalu menabrak lambung kiri KRI Tjiptadi. Sedangkan KN 231 menabrak KIAV BD 979 hingga mengalami kebocoran dan tenggelam. Dua ABK KIAV BD 979 sempat melompat kelaut dan ditolong oleh kapal pengawas perikanan milik Vietnam. Meski demikian, KRI Tjiptadi-381 tetap bisa menangkap 12 anak buah kapal (ABK) KIAV BD 979. Selanjutnya ke-12 ABK Kapal Vietnam dibawa dan akan diserahkan ke Lanal Ranai guna proses hukum selanjutnya. Dalam kasus ini Hukum Internasional yang dilanggar adalah International Regulations for Preventing Collisions at Sea (Peraturan Internasional untuk Mencegah Tabrakan di Laut) 1972 (COLREGs), dan International Convention for the Safety of Life at Sea (Konvensi Internasional untuk

\footnotetext{
8 Ibid. hlm. 100.

9/bid. hlm. $100 \quad$ (Lihat https://regional.kompas.com/read/2019/04/29/08345151 /2-kapal-pemerintah-vietnam-tabrak-kri-tjiptadi-381yang-sedang-patroli, diakses pada Tanggal 16 November 2019, Pukul 11.40 WIB.
} 
Keselamatan Kehidupan di Laut) 1974 (SOLAS). ${ }^{10}$

Direktorat Polisi Air dan Udara Barhakam Polri mendapati 952 kasus di perairan Indonesia sejak Januari hingga November 2018. Kasus terbanyak merupakan illegal fishing. Dirpolair Korpolairud Barhakam Polri Brigjen Lotharia Latif mengatakan illegal fishing masih menjadi permasalahan teratas di perairan Indonesia. Tercatat ada sebanyak 376 kasus yang 17 di antaranya merupakan kapal ikan asing."Yang masih menjadi berita hangat adalah illegal fishing di perairan Indonesia, itu jumlah yang kita laksanakan dalam rangka penegakan hukum ada 376 kasus di mana kapal ikan Indonesia ada 359 dan kapal ikan asing 17 kasus," ujarnya saat jumpa pers di Markas Ditpolair Barhakam Polri, Tanjung Priok, Jakarta Utara, Jumat (30/11/2018). Latif merinci, dari 17 kapal ikan asing, 12 di antaranya kapal berbendera Vietnam yang melakukan illegal fishing di Perairan Natuna. Lalu, 5 kapal lain berasal dari Malaysia. ${ }^{11}$

Kemudian wilayah penegakan kapal ikan asing yang paling tinggi ada di Perairan Natuna yaitu 12 kasus, memang ini relevan karena berbatasan dengan wilayah perbatasan. Terus sisanya kapal Malaysia yang tertangkap di wilayah Aceh, Perairan Sumatera Utara, Perairan Riau, dan Perairan Kaltim. Kasus lainnya yang tercatat ialah penggunaan bahan peledak 110 kasus, pencurian 62 kasus, perlindungan pekerja imigran Indonesia 6 kasus, migas 47 kasus, illegal logging 44 kasus, illegal minning 21 kasus, penyelundupan 12 kasus, kepabeanan 16 kasus, dan perompakan 14 kasus. $^{12}$

Kejahatan dapat terjadi di mana dan kapan pun. Timbulnya kejahatan menunjukkan bahwa di masyarakat telah terjadi kesenjangan sosial, banyak terjadi pengangguran. Kejahatan terorganisasi dalam bentuk pencurian ikan di laut, saat ini sedang marak dilakukan oleh kapal penangkap ikan di perairan luat Indonesia. Ada hal yang biasanya dilupakan, pelaku kejahatan umumnya hanya ingin mendapatkan uang

\footnotetext{
${ }^{10} \mathrm{lbid}$. hlm. 101.

${ }^{11} / \mathrm{bid}$. hlm. 111 (Lihat https://news.detik.com/berita/d4324943/baharkam-tangani-952-kasus-perairan-selama2018, diakses pada Tanggal 19 November 2019, Pukul 06.32 WIB.

12 Rahmawati Novia Sigit. Op.Cit. hlm. 111.
}

dengan cara pintas, mencuri kekayaan laut dengan merampok atau merompak. ${ }^{13}$ Modus operasi kejahatan di laut dikelompokkan menjadi bentuk pencurian, penyelundupan dan perompakan. ${ }^{14}$

Seperti dalam penindakan illegal fishing, pihaknya berkoordinasi dengan KKP. Karena itu, kata Arie, untuk penindakan kasus illegal fishing, lebih banyak dilakukan KKP ketimbang Bakamla, mengingat minimnya kapal. Mungkin untuk sekarang ini KKP (lebih banyak menindak), karena kapalnya lebih banyak dan lebih siap. (Bakamla cuma enam kapal) kalau KKP ada 39. Namun, Arie mengakui, selama ini tidak ada ketimpangan saat penindakan kasus illegal fishing di laut, karena Bakamla cuma ada enam kapal dan satu zona itu dua, saat operasi bersama yang banyak menangkap KKP. ${ }^{15}$

Penyebab terjadinya kegiatan illegal fishing di perairan Indonesia, antara lain, adalah:

1. Terbatasnya sarana dan prasarana pengawasan;

2. Terbatasnya dana untuk operasional pengawasan;

3. Terbatasnya tenaga polisi perikanan dan Penyidik Pegawai Negeri Sipil (PPNS);

4. Masih terbatasnya kemampuan nelayan Indonesia dalam memanfaatkan potensi perikanan di perairan Indonesia, terutama ZEE;

5. Kebutuhan sumber bahan baku di negara pelaku illegal fishing sudah menipis akibat praktik industrialisasi kapal penangkapnya sehingga daya tumbuh ikan tidak sebanding dengan jumlah yang ditangkap, dan sebagai akibatnya, mereka melakukan ekspansi hingga ke wilayah Indonesia;

6. Kemampuan memantau setiap gerak kapal patroli pengawasan di laut dapat diketahui oleh kapal ikan asing karena alat komunikasi yang canggih, sehingga hasil operasi tidak optimal. ${ }^{16}$

Terjadinya illegal fishing juga dipicu oleh kebutuhan dan permintaan stok ikan tertentu yang mempunyai nilai ekonomi tinggi,

\footnotetext{
${ }^{13}$ Sukandarrumidi, Op.Cit. hlm. 29.

$14 \mathrm{lbid}, \mathrm{hlm} .172$.

$15 \mathrm{lbid}$.

${ }^{16}$ Simela Victor Muhamad, Illegal Fishing di Perairan Indonesia: Permasalahan dan Upaya Penanganannya Secara Bilateral di Kawasan, Politica Vol. 3, No. 1, Mei 2012, hlm. 72.
} 
khususnya yang merupakan konsumsi pengunjung restoran-restoran mahal di luar negeri. Illegal fishing terhadap ikan pelagis besar, sebagai misal, banyak dilakukan di kawasan ZEE Indonesia yang dilakukan oleh kapal-kapal asing yang memiliki teknologi penangkapan ikan canggih. Bahkan dalam kapal-kapal asing tersebut telah dilengkapi berbagai perangkat untuk mendukung penyimpanan dan pengolahan ikan agar tetap segar dan memiliki nilai ekonomi tinggi ketika dijual di pasar internasional. Ini artinya, para pelaku illegal fishing memang menaruh perhatian besar terhadap potensi sumber daya perikanan laut Indonesia. Wilayah perairan laut Indonesia yang luas dengan segala keterbatasan sarana dan prasarana pengawasannya tampaknya tidak menjadi kendala bagi para pelaku illegal fishing untuk terus melakukan kegiatan ilegalnya di perairan Indonesia. ${ }^{17}$

\section{B. Penangan Pelanggaran Hukum di Zone Ekonomi Ekslusif Peraian Natuna}

Undang-undang Republik Indonesia Nomor 45 Tahun 2009 atas perubahan Undang-undang Nomor 31 Tahun 2004 tentang perikanan telah memuat regulasi atau formulasi baik mengenai hukum acara pidana maupun tindak pidana perikanan. Institusi negara yang berwenang melakukan tindakan penyidikan, penuntutan, dan mengadili tindak pidana illegal fishing antara lain Departemen Kelautan dan Perikanan,TNI Angkatan Laut, POLRI, Kejaksaan Dan Pengadilan Perikanan atau Pengadilan Negeri. ${ }^{18}$

Keputusan Menteri Kelautan dan Perikanan Republik Indonesia Nomor KEP.50/MEN/2012 tentang Rencana Aksi Nasional Pencegahan dan Penanggulangan Illegal, Unreported, and Unregulated Fishing (IUU Fishing). IUU Fishing adalah kegiatan perikanan yang tidak sah atau secara illegal yang tidak sesuai dengan peraturan yang berlaku. Adanya penetapan keputusan menteri yang mengatur tentang IUU Fishing bertujuan untuk mencegah dan menanggulangi terjadinya IUU fishing yang semakin marak terjadi yang dapat menimbulkan kerugian Negara salah satunya di bidang ekonomi, karena dapat berdampak pada

\footnotetext{
$17 \mathrm{lbid}, \mathrm{hlm} .73$.

18/bid. hlm. 51-52.
}

kerugian produk sumber daya ikan yang berpengaruh pada pendapatan Indonesia. Serta mendukung pengelolaan dan pembangunan perikanan yang tertib, harus lebih disosialisasikan dan diterapkan dengan baik untuk meningkatkan pencegahan terhadap IUU Fishing. ${ }^{19}$

Undang-Undang Nomor 45 Tahun 2009 tentang perikanan. Undang-Undang ini digunakan pemerintah sebagai dasar untuk menjaga sumber daya perikanan. Pemerintah harus berani mengambil tindakan cepat dan tepat untuk memutuskan setiap tindak pidana illegal fishing yang ada. Eksekusi penenggelaman kapal dapat dilakukan. Kapal asing yang melakukan pelanggaran dapat ditembak, diledakkan dan ditenggelamkan oleh penegak hukum kelautan di Indonesia. Dasar hukum penenggelaman kapal asing dapat ditemukan pada Undang-Undang No 45 Tahun 2009 Pasal 69 ayat 4 perikanan yang berbunyi :

1. Kapal pengawas perikanan berfungsi melaksanakan pengawasan dan penegakan hukum di bidang perikanan dalam wilayah pengelolaan perikanan Negara Republik Indonesia.

2. Kapal pengawas perikanan sebagaimana dimaksud pada ayat (1), dapat dilengkapi dengan senjata api.

3. Kapal pengawas perikanan dapat menghentikan, memeriksa, membawa, dan menahan kapal yang diduga atau patut diduga melakukan pelanggaran di wilayah pengelolaan perikanan Negara Republik Indonesia ke pelabuhan terdekat untuk pemrosesan lebih lanjut.

4. Dalam melaksanakan fungsi sebagaimana dimaksud pada ayat (1) penyidik dan/atau pengawas perikanan dapat melakukan tindakan khusus berupa pembakaran dan/atau penenggelaman kapal perikanan yang berbendera asing berdasarkan bukti permulaan yang cukup. $^{20}$

\footnotetext{
19/bid. hlm. 54-55.

${ }^{20}$ Gayuh Nugroho Dwi Putranto, Muhammad Zid dan Mieke Miarsyah. Konflik Batas Maritim, Illegal Fishing dan Upaya Penegakannya di Wilayah Laut Natuna antara Indonesia dan China (Maritim Limit Conflict, llegal Fishing and Enformance of Effort in Natuna Sea Region between Indonesia and China).Jurnal Perikanan dan Kelautan pISSN 2089-3469.Volume 9 Nomor 2.Desember 2019.eISSN 2540-9484. Halaman : 185-193.hlm. 191.
} 
Berdasarkan laporan Kementerian Kelautan dan Perikanan (KKP), sepanjang tahun 2015 penindakan hukum yang dilakukan oleh KKP berupa penenggelaman kapal, pemeriksaan, pemulangan anak buah kapal (ABK), dan penangkapan terhadap kapal ilegal. Pemerintah telah menenggelamkan sebanyak 113 kapal ilegal berbagai negara seperti Malaysia, Filipina, Vietnam, Thailand, Papua Nugini, Tiongkok, Panama, dan lainnya; memeriksa 23.041 kapal; memulangkan ABK asing sebanyak 1.020 orang atas kasus perbudakan; serta menangkap 157 unit kapal ilegal sepanjang tahun 2015 (Kementerian Kelautan dan Perikanan 2016). Kemudian pada tahun 2016, penindakan hukum berupa proses lebih lanjut oleh aparat dilakukan terhadap 136 unit kapal dari 149 unit kapal ikan asing yang melakukan pelanggaran illegal fishing (Kementerian Kelautan dan Perikanan 2017). ${ }^{21}$

Hingga Maret 2017, pemerintah melalui Satuan Tugas (Satgas) 511 telah menenggelamkan $317 \mathrm{kapal}$ asing. Satgas 511 sendiri adalah kerja sama multi instansi antara Kementerian Kelautan dan Perikanan, TNI Angkatan Laut, Kepolisian RI, dan Kejaksaan Agung untuk pemberantasan illegal fishing. Satgas ini dibentuk melalui Peraturan Presiden Nomor 115 tahun 2015 (Yakti and Susanto, 2017). Selain itu, pemerintah Indonesia juga secara aktif melakukan pengawasan melalui Operasi Kapal Pengawas di Wilayah Pengelolaan Perikanan Negara Republik Indonesia (WWP-NRI) dengan rata-rata hari operasi sebanyak 277 hari layar di wilayah barat dan di wilayah timur sebanyak 257 hari layar. Tujuan pengawasan tersebut adalah dalam rangka mengawasi sumber daya kelautan dan perikanan di seluruh WWP-NRI (Kementerian Kelautan dan Perikanan, 2016). Hasilnya adalah, sepanjang tahun 2016, sebanyak 149 kapal ikan asing dihentikan dan diperiksa serta 140 kapal ditahan oleh kapal pengawas (Kementerian Kelautan dan Perikanan, 2017).22

Bakamla yang kini menjadi salah satu lembaga pengamanan laut berdasarkan amanat Undang Undang No. 32 Tahun 2014 tentang Kelautan juga dapat menjalankan fungsi diplomasi. Eksistensi Bakamla dalam menjaga keamanan maritim kini tidak hanya

${ }^{21}$ Rahmawati Novia Sigit. Op.Cit. hlm. 114-115.

22 lbid. hlm. 115. diperlihatkan di tingkat domestik, tetapi juga dalam tataran bilateral, regional maupun global. Tercatat Bakamla telah menyelenggarakan kegiatan yang dikategorikan sebagai bagian dari cooperative maritime diplomacy melalui pelaksanaan HACGAM dan kunjungan kerja Bakamla sebagai representatif coast guard Indonesia ke Beijing, Cina pada November 2016. Kedua upaya tersebut merupakan bentuk diplomasi maritim yang memiliki tujuan untuk membina hubungan baik, dan saling meningkatkan capacity building. Di mana apabila ditingkatkan dapat menciptakan rasa saling percaya sehingga incident dalam kasus illegal fishing oleh nelayan Cina seperti yang telah terjadi sebelumnya dapat dihindari. ${ }^{23}$

Hukum diplomatik pada hakikatnya merupakan ketentuan atau prinsip-prinsip hukum internasional yang mengatur hubungan diplomatik antar negara yang dilakukan atas dasar permufakatan bersama dan ketentuan tersebut dituangkan dalam instrumeninstrumen hukum sebagai hasil kodifikasi hukum kebiasaan internasional dan perkembangan hukum internasional. ${ }^{24}$

Dengan meningkatnya kerjasama antarnegara dalam menggalang perdamaian dunia demi kesejahteraan umat manusia berdasarkan kemerdekaan dan keadilan sosial, maka tugas misi diplomatik dalam pelaksanaannya semakin meningkat pula, oleh karena itu perwakilan diplomatik di suatu negara sangatlah diperlukan. ${ }^{25}$ Hubungan diplomatik sebagai salah satu instrumen hubungan luar negeri, merupakan kebutuhan bagi setiap negara. ${ }^{26}$ Perkembangan yang terjadi di tingkat nasional dan internasional dapat memberikan peluang dan tantangan yang lebih besar bagi penyelenggaraan hubungan luar negeri. Hal ini didasarkan pertimbangan bahwa sejak dulu sampai saat ini tidak ada satu

\footnotetext{
${ }^{23}$ Ela Riska. Op.Cit. hlm. 41.

${ }^{24}$ Syahmin A.K., Hukum Diplomatik Suatu Pengantar. CV Armico. Bandung. 1988. hlm.14.

${ }^{25}$ Edy Suryono. Perkembangan Hukum Diplomatik. Mandar Maju. Bandung. 1992. hlm. 32.

${ }^{26}$ Widodo Hukum Diplomatik dan Konsuler Pada Eropa Globalisasi, LaksBang Justitia, Surabaya, 2009, hlm.1. (Lihat Sumarsono Mestoko, Indonesia dan Hubungan Antar-Bangsa, Sinar Harapan, Jakarta, 1988, hlm.5).
} 
pun negara yang dapat berdiri sendiri tanpa mengadakan hubungan internasional. ${ }^{27}$

Saat ini perkembangan dunia yang ditandai dengan pesatnya kemajuan ilmu pengetahuan dan teknologi telah meningkatkan intensitas hubungan dan interdependensi antar-negara. Sejalan dengan peningkatan hubungan tersebut, maka makin meningkat pula kerja sama internasional. Konvensi Wina Tahun 1961 tentang Hubungan Diplomatik, Konvensi Wina Tahun 1963 tentang Hubungan Konsuler, serta Konvensi New York Tahun 1969 tentang Utusan Khusus menjadi pedoman pokok hubungan antarnegara dan antarorganisasi internasional. ${ }^{28}$ Dalam membina hubungan antar negara tersebut, hukum diplomatik menjadi sesuatu yang penting dipahami. ${ }^{29}$

Dalam rangka menjalankan tugas dan fungsinya, para pejabat diplomatik tersebut memiliki perbedaan-perbedan yang prinsipiil. Bagi misi perwakilan tidak tetap (sementara), fungsinya terdapat pada tugas yang diserahkan kepada wakil diplomatik itu untuk menangani masalah-masalah tertentu sesuai dengan isi surat kepercayaan yang diberikan kepada mereka untuk hal-hal khusus. ${ }^{30}$

Tugas dan fungsi perwakilan diplomatik tetap bersifat sangat luas dan sudah ditentukan sebagai terbatas dalam konvensi Wina 1961 Pasal 3 ayat (1) adalah sebagai berikut:

1. Mewakili negaranya di negara penerima.

2. Melindungi kepentingan negara pengirim di negara penerima dalam batas-batas yang diperkenankan oleh hukum internasional.

3. Mengadakan perundingan-perundingan dengan pemerintah di mana mereka diakreditasikan.

4. Memberikan laporan kepada negara pengirim mengenai keadaan-keadaan dan perkembangan-perkembangan di negara penerima dengan cara-cara yang dapat dibenarkan oleh hukum.

\footnotetext{
$27 \mathrm{lbid}$. hlm. 1.

${ }^{28} \mathrm{lbid}$, hlm.2. (Lihat Widodo, Konsep dan Dinamika Hukum Internasional, Indonesian Bussiness School, Malang, 1997, hlm. 48).

${ }^{29} \mathrm{lbid}$, hlm.2. (Lihat Syahmin A.K., Hukum Diplomatik dalam Kerangka Studi Analisis, Rajagrafindo Persada, Jakarta, 2008, hlm.7).

${ }^{30}$ Setyo Widagdo dan Hanif Nur Widhiyanti, Hukum Diplomatik dan Konsuler, Bayumedia Publishing, Malang, 2008, hlm. 51.
}

5. Meningkatkan hubungan persahabatan antarnegara, terutama dengan negara pengirim dan negara penerima serta mengembangkan dan memperluas hubungan-hubungan ekonomi, kebudayaan, dan ilmu pengetahuan antarnegara.

Undang-Undang Nomor 32 Tahun 2014 tentang Kelautan, Pasal 59 ayat (3). Dalam rangka penegakan hukum di wilayah perairan dan wilayah yurisdiksi, khususnya dalam melaksanakan patroli keamanan dan keselamatan di wilayah perairan dan wilayah yurisdiksi Indonesia, dibentuk Badan Keamanan Laut.

Pasal 60. Badan Keamanan Laut sebagaimana dimaksud dalam Pasal 59 ayat (3) merupakan lembaga pemerintah nonkementerian yang berkedudukan di bawah dan bertanggung jawab langsung kepada Presiden melalui menteri yang mengoordinasikannya. Pasal 61. Badan Keamanan Laut mempunyai tugas melakukan patroli keamanan dan keselamatan di wilayah perairan Indonesia dan wilayah yurisdiksi Indonesia.

Peraturan Presiden Republik Indonesia Nomor 178 Tahun 2014 tentang Badan Keamanan Laut.

(1) Badan Keamanan Laut yang selanjutnya dalam Peraturan Presiden ini disebut Bakamla dikoordinasikan oleh Menteri Koordinator Bidang Politik, Hukum dan Keamanan.

(2) Dalam hal pengelolaan dan pemanfaatan sumber daya laut, Menteri Menteri Koordinator Bidang Politik, Hukum dan Keamanan berkoordinasi dengan Menteri Koordinator Bidang Kemaritiman.

(3) Bakamla bertanggung jawab kepada Presiden melalui Menteri Koordinator Bidang Politik, Hukum dan Keamanan.

\section{PENUTUP}

\section{A. Kesimpulan}

1. Terjadinya pelanggaran hukum di zona ekonomi eksklusif perairan natuna, seperti kegiatan illegal fishing yang dilakukan oleh nelayan-nelayan asing dari Cina, Vietnam. Kasus lainnya yang tercatat ialah penggunaan bahan peledak 
pencurian, penyelundupan pekerja imigran Indonesia, migas, illegal logging, illegal minning, penyelundupan kepabeanan dan perompakan. Perairan yang rawan pencurian, antara lain, laut Natuna yang berbatasan dengan laut Cina Selatan, perairan Sulawesi Utara yang berbatasan dengan Samudra Pasifik dan Laut Arafura. Pencurian ikan oleh kapal-kapal asing dilakukan secara terang-terangan, menggunakan alat tangkap pukat harimau (trawl). Penyebab terjadinya kegiatan illegal fishing di perairan Indonesia, antara lain, karena terbatasnya sarana dan prasarana pengawasan untuk melakukan penegakan hukum.

2. Penanganan pelanggaran hukum di zona ekonomi eksklusif perairan natuna, dilakukan melalui upaya penegakan hukum oleh instansi pemerintah terkait yang mengatur bidang kelautan.

\section{B. Saran}

1. Terjadinya pelanggaran hukum di zona ekonomi eksklusif perairan natuna, memerlukan pemantauan, evaluasi dan pelaporan guna mencegah terjadinya penangkapan ikan secara ilegal dan kerjasama antarinstansi pemerintah terkait di bidang kelautan memerlukan dukungan sarana dan prasarana yang memadai agar upaya penegakan hukum dapat dilaksanakan secara efektif.

2. Penanganan pelanggaran hukum di zona ekonomi eksklusif perairan natuna, memerlukan koordinasi antarinstansi pemerintah terkait dengan melibatkan peran masyarakat khususnya masyarakat nelayan utuk membantu menjaga dan memberantas penangkapan ikan secara ilegal di zona ekonomi eksklusif perairan natuna.

\section{DAFTAR PUSTAKA}

Agoes R. Etty (Penyunting) Dimanahkah BatasBatas Wilayah Kita Di Laut ? Departemen Kelautan dan Perikanan, Jakarta, 13 Desember 2000.

A.K.Syahmin, Hukum Diplomatik Suatu Pengantar. CV Armico. Bandung. 1988.
Anwar Chairul, ZEE Zona Ekonomi Eksklusif Di Dalam Hukum Internasional Dilengkapi Dengan Analisis Zona Ekonomi Eksklusif Indonesia dan Zona Ekonomi Eksklusif Asia Pasifik, Cetakan Pertama, Sinar Garfika Jakarta, Oktober 1995.

Bahari Mina, Edisi Khusus, Tenggelamkan Kapal KKP Rangkul Elemen Pemerintah, Kementerian Kelautan dan Perikanan, Jakarta, 2015, hlm. 24.

Damastuti Aji Tiara, Rivinta Cahyu Hendrianti, Roro oktavia Laras dan Rahmawati Agustina, Penyelesaian Sengketa Ilegal Fishing Di Wilayah Laut Natuna antara Indonesia Dengan China. Jurnal Reformasi Hukum : Cogito Ergo Sum ISSN 2599-3364 (print) Volume 1, Nomor 2, Juli 2018, 51-58 ISSN 26145987 (online).

Hamzah Andi, Terminologi Hukum Pidana, (Editor) Tarmizi, Ed. 1. Cet. 1. Sinar Grafika, Jakarta, 2008.

Hariri Muhwan Wawan. Pengantar Ilmu Hukum, Cet. 1. CV. Pustaka Setia Bandung. 2012.

Husni Lalu, Pengantar Hukum Ketenagakerjaan Indonesia, Edisi Revisi, PT. RajaGrafindo, Jakarta, 2008.

Kusumaatmadja Mochtar, Bunga Rampai Hukum Laut, Cetakan Pertama, Jakarta, Agustus, 2008.

Mahmud Marzuki Peter, Penelitian Hukum, Edisi Pertama Cetakan ke-2, Kencana Prenada Media Group, Jakarta, 2006.

Marbun Rocky, Deni Bram, Yuliasara Isnaeni dan Nusya A., Kamus Hukum Lengkap (Mencakup Istilah Hukum \& PerundangUndangan Terbaru, Cetakan Pertama, Visimedia, Jakarta. 2012.

Marpaung Leden, Asas-Teori-Praktik Hukum Pidana, Sinar Grafika. Cetakan Kedua, Jakarta. 2005.

Masriani Tiena Yulies, Pengantar Hukum Indonesia, Cetakan Kelima, Sinar Grafika, Jakarta, November 2009.

Muhamad Victor Simela, Illegal Fishing di Perairan Indonesia: Permasalahan dan Upaya Penanganannya Secara Bilateral di Kawasan, Politica Vol. 3, No. 1, Mei 2012.

Novianto Dwi Rizal, Dimas Agung Firmansyah dan Naufal Adi Pratama. Penyelesaian 
Sengketa Di Laut Natuna Utara. Jurnal Hukum Bisnis Bonum Commune Volume 3 Nomor 1 Februari 2020.

Nugroho Gayuh, Dwi Putranto, Muhammad Zid dan Mieke Miarsyah. Konflik Batas Maritim, Illegal Fishing dan Upaya Penegakannya di Wilayah Laut Natuna antara Indonesia dan China (Maritim Limit Conflict, llegal Fishing and Enformance of Effort in Natuna Sea Region between Indonesia and China).Jurnal Perikanan dan Kelautan pISSN 2089-3469.Volume 9 Nomor 2.Desember 2019.e-ISSN 25409484. Halaman : 185-193.

Nuraeny Henny, Tindak Pidana Perdagangan Orang, (Kebijakan Hukum Pidana dan Pencegahannya), Cetakan Pertama, Sinar Grafika, Jakarta, 2011.

Riska Ela. Diplomasi Maritim Indonesia Terhadap Aktivitas Penangkapan Ikan llegal (Illegal Fishing) Oleh Nelayan China Di Zeei Perairan Kepulauan Natuna Indonesia Maritime Diplomacy Towards Chinese Fishermen Illegal Fishing Activities In The Indonesia Eez In Natuna Islands Water. Jurnal Prodi Diplomasi Pertahanan | Juni 2017 | Volume 3 Nomor 2.

Sadjijono, Polri Dalam Perkembangan Hukum Di Indonesia, (Editor) M. Khoidin, LaksBang PRESSindo, Yogyakarta, 2008.

Sigit Novia Rahmawati. Penyelesaian Kasus Pelanggaran Hukum Di Perairan Natuna Yang Dilakukan Oleh Kapal Asing Vietnam Dalam Perspektif Hukum Laut Internasional. Jurnal Selat Volume. 7 Nomor. 1, Oktober 2019. p-2354-8649 I e -2579-5767.

Soekanto Soerjono, Pengantar Penelitian Hukum, UI Press, Jakarta, 2005.

Soekanto Soerjono dan Sri Mamudji, Penelitian Hukum Normatif Suatu Tinjauan Singkat, PT Raja Grafindo Persada, Jakarta. 1995.

Soekanto Soerjono, Faktor-Faktor Yang Mempengaruhi Penegakan Hukum, RajaGrafindo Persada, 2010, Jakarta, 2010.

Sudarsono, Kamus Hukum, Cet. 6. Rineka Cipta, Jakarta, 2009.
Sukandarrumidi, Mari Kembali Ke Laut (Mengenal Potensi Bahari Yang Tak Habis Terkuras) Dengan Studi Kasus, Cetakan Pertama, Yayasan Pustaka Nusatama, Yogyakarta, 2009.

Suryono Edy. Perkembangan Hukum Diplomatik. Mandar Maju. Bandung. 1992.

Thontowi Jawahir dan Pranoto Iskandar, Hukum Internasional Kontemporer, PT. Refika Aditama, Bandung, 2006.

Usman, Aspek-Aspek Hukum Perbankan di Indonesia. Penerbit Gramedia Pustaka Utama. Jakarta. 2001.

Wahyuni Sri. Strategi Pemerintah Indonesia Dalam Penyelesaian Konflik Klaim Traditional Fishing Ground Pada Zona Ekonomi Ekslusif Indonesia Di Perairan Natuna Oleh Republik Rakyat Tiongkok. Sosioreligius Nomor IV Volume 2. Desember 2019.

Widagdo Setyo dan Hanif Nur Widhiyanti, Hukum Diplomatik dan Konsuler, Bayumedia Publishing, Malang, 2008.

Widodo. Hukum Diplomatik dan Konsuler Pada Eropa Globalisasi, LaksBang Justitia, Surabaya, 2009.

\section{Internet \\ https://kumparan.com/alviana-rizky.Peran Dan Fungsi Hukum Internasional Dalam Hubungan Internasional. Diunduh 11/16/2019 1:27. \\ https://indocropcircles.wordpress.com/201 6/06/21/cina-akui-natuna-milik-indonesia- tapi-inilah-masalahnya}

